\title{
WHO WAS THE FIRST PHILOSOPHER? OR, HOW MANY PHILOSOPHERS DOES IT TAKE? \\ James Alexander
}

The first philosopher is usually said to have been Thales. Raymond Geuss has recently suggested that it was not Thales but Oedipus (and the Sphinx), on the grounds that 'It takes two' for philosophy to exist. Slavoj Žižek, on the other hand, has suggested that 'It takes one': in which case the first philosopher may well have been Thales. Here I argue that 'It takes three' and that the first philosopher was not the first to have a vision, and not the first to answer a riddle, but the first to hear two sides of a question and make sense of both.

The standard story about the origin of philosophy is that it emerged with Thales in the early sixth century BC. At this time philosophy was indistinguishable from physical science: Thales was an astronomer and a geometer. The claim that he was the first philosopher depends on the view that he was the first to say that everything in the universe is made of the same thing - water - and therefore that the same laws apply to everything. Aristotle called him the first scientist; Hegel considered him the first philosopher of the Greeks, and therefore the first real philosopher, and, as everyone knows, Russell's History of Western Philosophy put Thales first in his long list of philosophers, and in so doing probably doing more than any other book to make the priority of Thales famous.

I had never thought much about the question of who was the first philosopher. I paid a bit more attention to the etymological question of the origin of the term philosophia, and the interesting fact that it was perhaps a Pythagorean invention which Socrates had taken up in order to 
distinguish what he was, a philosophos, someone who loved wisdom without claiming to possess it, from others who claimed to be sophoi, wise men, or sophists. But I left it there, since the Presocratic philosophers were intriguing, fragmentary and obscure, and not of much direct interest. Then I read an essay entitled 'Who Was the First Philosopher?' by the Cambridge philosopher Raymond Geuss, published in his book A World Without Why. ${ }^{1}$ Here, Geuss made an arresting claim. He said that philosophy is not a solitary activity: it is, on the contrary, something which only exists in conversation. So he argued that the first philosopher was Oedipus. Or, rather, he argued that the first philosophers were Oedipus and the Sphinx. The fact that this philosophical exchange ended in a death did not disturb Geuss. What interested him more was that the exchange took the form of a question and an answer, that the question was a riddle and the answer resolved the riddle, and that the answer to the riddle was the answerer himself, who, in answering it, destroyed the mystique and obscurity of the questioner. The question was, of course, 'What walks on four legs in the morning, two legs in the afternoon, and three legs in the evening?', and the answer was 'Man'.

Geuss's argument surprised me, or provoked me, because I had recently written an essay which offered a sketch of philosophical activity in its entirety. It is not that his argument contradicted mine, but that I had not even thought about whether philosophy takes place in the mind, or on the page, or in conversation: I was more concerned with four completely distinct paradigms of reflection: (1) wonder, in which we respond wordlessly to the world and call that experience truth; (2) faith, in which we respond to a word about the world and call that word truth; (3) doubt, in which we respond to contradictory words and call our overcoming of doubt truth; and (4) scepticism, in which we respond to contradictory words by saying that the truth is there is no truth. I simplify the argument, but that is more or less it. ${ }^{2}$ In this essay of mine I polemicized a bit against 
doubt, saying that sometimes philosophers write as if this is the only genuine form of philosophy. And what is interesting is that wonder, faith and scepticism are a bit more resolute without conversation than doubt. Doubt seems to be the form of philosophy which makes sense of conversation. We have a conversation, there is a doubt, different possibilities are discussed, reason is found for one of the possibilities, or evidence for it, and doubt is overcome, leaving us with certainty.

So Geuss's argument was, more or less, that we should think of philosophy as a dialogue. The problem, it seems to me, is that Oedipus and the Sphinx did not exactly argue or have a conversation. The Sphinx asked a riddle, which was a question of life and death - not because it is a question of life and death, but because of some caprice in her which made it so (she would throw off the cliff anyone who could not answer the question) - and, since Oedipus answered it, she threw herself off the cliff. This is dramatically effective, though still surprising. Hegel interpreted this story as the triumph of Greek self-consciousness over Asiatic obscurity: even the fact that the question is asked by a Sphinx was taken by Hegel to be important. Anyhow, Geuss followed Hegel in thinking that there is some achievement expressed in this story: the man not only is a man but recognizes he is, and articulates it, and so becomes aware of himself in a new way.

I wouldn't have thought about this any further had I not bought a book of conversations with Slavoj Žižek yesterday. I had not really succeeded in reading anything by Žižek not any of his books, not even his book of arguments with Butler and Laclau about politics, or his book of arguments with Milbank about Christianity. His style is too boisterous, flitting between absurd sincerity and coat-trailing insincerity. There is always a doubt about anyone who takes Lacan as an authority. So far I had just noted Žižek down as England's favourite Frenchman (who is, of course, not French: which says something about the English sense of humour): find a Slovenian who sat at the feet of the man 
(Jacques Alain-Miller) who sat at the feet of Lacan, Lacan's grandson, as it were, and let him explain everything the readers of the London Review of Books need to know about arcane foreign thought. It is common for 'continental' philosophers, especially the French, to appear in books of conversations: Foucault is better in conversation and in his lectures than in his books. It is as if these obscure philosophers 'come off it' a bit occasionally when they are talking, even if they also show how fluent their obscurity is. So I bought these conversations with Žižek.

In one conversation, Žižek expressed disagreement with Geuss. Whereas Geuss said the first philosopher was the one to have a conversation, Žižek said - in a conversation, we may note - that this is not so. I will quote him at some length from Conversations with Žižek:

I am dogmatic. It took me some time to learn this, but I think that I truly became a philosopher when I understood that there is no dialogue in philosophy. Plato's dialogues, for example, are clearly fake dialogues, in which one guy is talking most of the time and the other guy is mostly saying 'yes I see, yes my God, it is like you said - Socrates, my God, that is how it is'. I fully sympathise with Deleuze who said somewhere that the moment a true philosopher hears a phrase like 'let's discuss this point', his response is 'let's leave as soon as possible; let's run away!' Show me one dialogue which really worked. There are none. I mean, of course, that there were influences that pass from one philosopher to another, but it can always be demonstrated that they were really misunderstandings. No, I think that with all radical, true philosophers, there is moment of blindness, and that is the price you have to pay for it. I don't believe in philosophy as a king of interdisciplinary project - that is the ultimate nightmare. That's not philosophy. We philosophers are madmen. ${ }^{3}$ 
We can simplify matters here. Geuss says 'Philosophy is a dialogue', and Žižek says, 'Philosophy is a monologue'. Geuss emphasizes question and answer. Žižek emphasizes a moment of insight. Geuss says, 'It takes two', and Žižek says, 'It takes one'. Geuss is known to be a philosopher who has spent a lot of time thinking about Nietzsche; but here it is Žižek who seems the more Nietzschean, arguing that a philosopher is a tyrant, a dictator. This, according to Nietzsche, was the Greek idea of the philosopher. A dictator simply wants to issue dicta, which may be what lawyers call obiter dicta, things said in passing, things not of the essence. This is dictatorship, of course: a condition in which a speaker has such a right to speak that they no longer distinguish between what they say of importance and what they say in passing. Geuss is more concerned with getting somewhere, not through divine insight, but through patient and collective reflection. He, unlike Deleuze, would say 'Yes, let's stay and discuss the point!'

I have a suggestion here, which came to me after reading the Žižek and recalling the Geuss. This is that philosophy does not take one, or two. It takes three. The first philosopher was not the first madman to have insight Žižek might well think Thales was the first philosopher nor was the first philosopher the first man to answer a question after some reflection. The first philosopher was the first man or woman (and for all we know it may well have been a woman) who heard two contrary dicta and thought to himself or herself, 'Oh, l'd better think about that!' Someone says $x$, and it is plausible; then someone says $y$, and that is plausible too: and so what are we to do? Well, something called philosophy, which is depending on what one supposes philosophy to involve, means attempting to see how one of the propositions $x$ or $y$ can be disproved, or shown to be inferior to some other proposition $z$, or - if one is Hegelian (as Žižek sometimes seems to be) - attempting to see how $x$ and $y$ could be reconciled in some dialectical understanding $z$. 
The first philosopher was not Parmenides. Nor was it Socrates. When the young Socrates spoke to the old Parmenides (in Plato's dialogue Parmenides) they were engaged in a conversation, or firing monologues past each other - we can understand the situation in both ways. But there was someone else there: Zeno, perhaps, who listened. Or, perhaps, Socrates not only took part in the dialogue, but also, with part of his mind, tracked the conversation, listened to it, and remembered enough of it to be able to tell Plato and his other followers about it much later on. In which case Socrates the spectator, rather than Socrates the actor, was the first philosopher. Or Plato, who was, it seems, par excellence, not someone who himself spoke in dialogues, but who wrote dialogues down. $\mathrm{He}$ did not write dialogues down because dialogue works. Žižek is of course right about the one-sided nature of most of the Platonic dialogues: even the successful arguments in Plato's writings, where two points of view are expressed, usually end in digression or myth-making or even, in the case of Thrasymachus, a simple expression of frustration. Plato wrote dialogues because that was the most important philosophical activity: the attempt to recapture, in one mind, the possibility of a difference of view. That is, in one mind, holding two ideas which were contradictory together at the same time: that was philosophy. Whoever did this first, was the first philosopher. Perhaps it was Plato.

Alan Watson, in one of his books on the history of law, notes that Greeks tended to resolve disputes through conciliation. It was the Romans who invented confrontation as a legal process: whereby the two claimants would make their claims on oath, submit evidence, and then submit themselves to the judgement of a third party. This is now the standard method of adjudicating legal cases. Of course, before conciliation and confrontation, there was decree: a king, who was also judge, would decide cases, more or less capriciously. And here, I think, we have three models, not only for law, but for philosophy. The philosopher may be, as Žižek suggests, a dictator, someone who 
decides by decree. Or the philosopher may be, as Geuss suggests, a conversationalist, someone who decides through deliberation. Or the philosopher may be, as I suggest here, a judge, who decides after hearing both sides of the case. Here, clearly, there is a sort of dialectic. Dictators may engage in deliberation; and, when they do, a third party may adjudicate between them. Philosophy is probably found at every point in this dialectic: and all I have done here is suggest a third place in which it may be found. The philosopher may be a spectator, as well as deliberator and a dictator.

I showed this argument to my brother. He said: 'Besides the three philosophers, there should be a fourth person, who says, "You lot appear to be philosophizing. I'm off to watch television."'

James Alexander teaches in the Department of Political Science, Bilkent University, Ankara. jalexand@bilkent.edu.tr

\section{Notes}

${ }^{1}$ Raymond Geuss, A World without Why (Princeton: Princeton University Press, 2014), 223-30.

${ }^{2}$ It can be found in 'The Four Points of the Compass', Philosophy 87 (2012), 79-107.

${ }^{3}$ Slavoj Žižek and Glyn Daly, Conversations with Žižek (Cambridge, MA: Polity, 2004), 41. 